\title{
The Early Childhood Mathematics Learning
}

\author{
Rusdawati \\ Early Childhood Education Department, Padang State University, Padang, Indonesia, ruskhadijah@yahoo.co.id
}

\begin{abstract}
Mathematics is one of the human knowledge needed in everyday life. This article aims to describe the learning of mathematics in early childhood. What is included in early childhood mathematics learning, and what steps can be done so that the learning of mathematics can be in a high value. In this article it is also discussed what principles should be used for math learning at school.
\end{abstract}

Keywords: Learning, Mathematics and Early Childhood

\section{INTRODUCTION}

According Wiyani (2014: 32) cited Antari .KY et al "Early childhood is a child who is born until the age of 6 years" early chilhood is the most good time to get a new knowledge. This age is an age that is decisive in shaping the character and personality of the child. Early childhood is the age when children experiencing rapid growth and development.

Early childhood education is the provision of an effort to stimulate, guiding, nurturing and providing learning activities that will result in the ability and skills of the child (Sujiono, Yuliani Conscience, 2009: 7). Efforts in providing stimulus to produce ability and skills then there are some aspects that could be given stimulus, in permendikbud No. 146 2014, there are six aspects of early childhood development: (1) religion and moral values, (2) cognitive, (3) language, (4) Physical motor, (5) social -emotional and (6) art. Six aspects of these developments can be developed to provide a natural stimulus age-appropriate development.

One of the aspects mentioned above are cognitive, according Supartini.E and Wati.D (2017) covers the cognitive development of children how to think, how children view their world, and about how children use playing equipment and materials for the study, which aimed to make children can learn to solve problems, think logically and symbolic thinking. Developing cognitive aspect as a part of the basic mathematical knowledge for early chilhood.

Recent mathematics teaching, children are often asked to memorize the geometric shapes, numbers, amount, variety of symbols and language of mathematics, without understand the underlying principles. If this happens, then it is very likely the child will experience difficulties when entering the 3rd grade. And then that's when we realized that children are in fact not understand the basic concepts of mathematics,

According to Bieber, KW (2011) Children have started to develop the mathematical concept of a variety of daily activities. For example, when a baby, small child knows that he and his father while the mother is great, even though the children can not express it in the spoken language.

When she was a toddler (under three years), the child knows that if he accumulates a beam on beam else then beam will multiply (so two) even though he can not express it in the spoken language. Kids also knew that he had two beams and her friend had ten beams, then his beams more so that the child wants to take it from their friends. In addition, children often choose their own toys even though he did not know the basis of his election. Kids also know his schedule in a day when it is done regularly.

Mastery of early math by an early chilhood is important because it is only a principle to help students understand the concepts of higher mathematics. Early mathematical learning gained through direct experience in an atmosphere encouraging and meaningfull which able to cultivate student interest to learn mathematics. According to Haryuni, S. (2013), Children have come to know and explore the various dimensions that cannot be separated from the mathematical number of the world they are, good to mention, recognize the concept or familiar symbol. It will help the child to life outside the school and will provide a solid foundation in learning in school.

\section{THE NATURE OF MATHEMATICS}

Mathematics is human knowledge needed to carry out their everyday lives. For example ranging from waking someone looking at the numbers contained on the clock to see what time it was, when shop then we will vote and count the number of items to be purchased and the price paid. As she walked away, we need to remember the street where that will be visited, how long away, and choose the path more can quickly reach the destination, etc.

According to Piaget quoted Charlesworth, R (2005) children acquire the knowledge to build it through their interaction with the environment, and Piaget divides knowledge into three areas of knowledge into three areas:

1. Physical knowledge is the type that includes learning about objects in the environment and their characteristics (color, weight, size, texture, 
and other features that can be determined through observation of and physically located in the objects.

2. Logic-mathematical knowledge is the type that includes a relationship (same and different, more and less, the amount, classification, etc.) that each individual make sense out of the world and to manage the informations.

3. Social knowledge (or conventional) is the kind made by the person (such as the rules for behavior in various situation.

Children need to solve issues through games and other activities which require their brain to think. They must work with the material made of concrete. In line with problem with NCTM focus on mathematics for understanding, Duckworth (2006) describes how Piaget's view understanding focuses on adult to appear to child's perspective. That is, we should not see "Understanding" from the standpoint of our own but it should be find out what people think about the child.

Math is basically learning to think or learn to solve problems. According to Dodge and Colker (2000: 49) cited Khasanah, matematika is the ability to create relationships. And to be a math thinker, children need to be given the opportunity to investigate, organize concrete objects before they can use the symbols that have been known in the abstract.

While the book materials only focus on children which make mathematics is an abstract system to experience inorganize and sort, and early childhood mathematics is defined as follows:

1. One-to-one including distribution objects that associated with direct relationships with each other, like a cake separately to each students.

2. Ordering including the ability to put something with the order, first by size (smallest to large) and then each numbers.

3. Counting including the ability to demonstrate understanding of numbers and amount.

4. Calculation is the process of addition and subtraction, in line with concrete experienced.

5. The classification includes the ability to sort objects based on the attributes (eg, color, shape, size).

6 Measurement is the process of finding the numbers from a standard unit of an object.

7. Comparison including the ability to determine that an object is larger, smaller, or the same as the others through measurements

8. Geometry is the study os space coorelation.

9. Pattern is a theme that connects mathematic topics in encourage children to look at the relationship, find a relationship and make general conclusions and forecasts.

Meanwhile, according to Lester, KW, When we think about mathematics, we will talk about the similarities and differences, setting the information / data, understanding of numbers, numbers, patterns, space, shapes, forecast and comparison. Knowledge of mathematics actually already be introduced to children at an early age (ages birth-6 years). For children under three years of age, mathematical concepts are discovered every day through the experience of play. For example, when distributing cake to each of his friends, pouring water from one container to other.

In the high-quality mathematics education for children, teachers, and other important professional at the age of 3 to 6 years old should be done according to Clements, $\mathrm{DH}$, Copple, C., \& Hyson, M. (2002) .:

1. Improving children's natural interest towards mathematics and their disposition to use them to understand their social and physical world

2. Build experience and knowledge of children, including family background, linguistic, cultural, and their communities; Their individual approach to learning; and the informations

3. Basic mathematics curriculum and teaching practices on young children's knowledge of cognitive, linguistic, physical, and socialemotional developments.

4. Use the curriculum and teaching practices that strengthen the process of problem solving and reasoning children and represent, communicate, and connecting mahematics idea.

5. Ensuring that the curriculum is coherent and in accordance with the relationship and sequence of important mathematical ideas

6. Give children interaction profound and sustained by the idea mathematics main Integrate mathematics with other activities and other activities with mathematics provide time, materials, and teacher support enough for children to get involved in the game, the context in which they explore and manipulate mathematical ideas with high interests.

7. Actively introduce the concepts, methods, and language of mathematics through various experiences and teaching strategies which appropriate.

8. Support children's learning by studying seriously and continuously assess all the knowledge, skills, and mathematic strategies children.

High-quality mathematics education will not be achieved when certain things should not implemented in early childhood learning and where teachers are still oriented on results and not only provide opportunities for children to understand mathematical concepts.

\section{PRINCIPLES - PRINCIPLES OF MATHEMATICS SCHOOL}

School Mathematical Principles is the statement reflects the basic rule that guides high-quality mathematics education. The following six themes of comprehensive teaching mathematics (NCTM, 2000, p11) quoted Charlesworth, R (2005) Equity: high expectations and strong support for all students Curriculum: More than just a collection of activities; coherent, focus on important 
mathematics, good in articulated in all values Teaching: Learning math effective need understanding to what students know and need to learn and then challenged and support the to study properly.

Learning: Students must learn mathematics with understanding, actively building new knowledge and previous knowledgefrom experience.

Assessment: Assessment must support and provide important mathematics learning information that useful for students and teachers.

Technology: Technology is essential in teaching and study mathematics; It affects matematics that is taught and improve students learning.

Above six principles should be used as a guide for teaching in all learning activities, not just mathematics. Learning should be designed as possible, so that the learning of mathematics into knowledge preferred and attractive mathematics which previously feared and boring.

To strengthen the foundations of mathematics learning in early childhood is necessary to build a positive attitude towards mathematics. To build a positive attitude towards learning mathematics necessary to prepare devices that support and adapted to the age of the child development curriculum, methods and devices. Good thing when learning of mathematics reflects all the characteristics of early childhood education, which can be applied in real life, even though the child is applying mathematics unconciously in life.

\section{CONCLUSION}

School Mathematical Principles is the statement reflects the basic rule that guides high-quality mathematics education. Mastery of early math by an early chilhood is important because it is only a principle to help students understand the concepts of higher mathematics. Early mathematical learning gained through direct experience in an atmosphere encouraging and meaningfull which able to cultivate student interest to learn mathematics. The nature and principles of math should be used as a guide for teaching in all learning activities, not just mathematics. Learning should be designed as possible, so that the learning of mathematics into knowledge preferred and attractive mathematics can be achieved.

\section{REFERENCES}

[1] Antari, KY, son, IKA, and Eternal, IB

[2] GS (2016). Application of visual learning model, auditory, aided kinestethic picture media concepts cognitive ability to increase number. Early Childhood Education Journal, 4 (1).

[3] Charlesworth, Rosalind (2005). Experiences In Math for Young children. The United State: Thomson Delmar Learning
[4] Clements, DH, Copple, C., \& Hyson, M. (2002). Early childhood mathematics:

[5] Promoting good beginnings. A joint position statement of the National Association for the Education of Young Children (NAEYC) and the National Council of Teachers of Mathematics (NCTM).

[6] Haryuni, S. (2013). Upgrades Know the Numbers Through Media Domino Triangle in early childhood I Kenanga South Coastal District. Spectrum PLS, 1 (01), 104-118.

[7] Lestari, KW (2011). Mathematical Concepts for Early Childhood. Jakarta: National KementrianPendidikan.

[8] Inawati, M. (2011) The concept of Know Your Interests Meningkatkan Numbers through Manipulatif. Pedoman Instrument Playing Method Writing for the Journal of Educational Sower, 1.

[9] Siswono, TYE (2012). Learning and Teaching Mathematics in Early Childhood. serial on line). http: // www. academia. edu / 4069396 / Belajar_dan_Menga jar_Mate matika_Anak_Usia_Dini [July 8, 2015].

[10] Khasanah, I. (2013). Logic math learning early childhood (ages 4-5 years) in jakarta TK Bulog TIMUR.PAUDIA, 2 (1 May) 